\title{
Study and comparison results of the field oriented control for photovoltaic water pumping system applied on two cities in Morocco
}

\author{
Mustapha Errouha, Aziz Derouich \\ Laboratory of Production Engineering, Energy and Sustainable Development, Higher school of technology, km 5 Rte \\ Imoouzzer, BP 2427, USMBA Fez Morocco
}

\begin{tabular}{l} 
Article Info \\
\hline Article history: \\
Received Aug 12, 2018 \\
Revised Dec 1, 2018 \\
Accepted May 28, 2019 \\
\hline Keywords: \\
Modeling and field oriented \\
control \\
Pumping water photovoltaic \\
system \\
PV cell \\
Variable step size incremental \\
conductance
\end{tabular}

\begin{abstract}
In this papier, a low-cost solar photovoltaic water pumping system based on an induction motor without the use of chemical energy storage is presented. In literature, we can find several Maximum Power Point Tracking Algorithms, the choice of the algorithm is according to the nature of application. In this article, Variable Step Size Incremental Conductance MPPT method has been developed since it is fast and has less oscillations. The studied photovoltaic pumping system contains a centrifugal pump which is driven by a three-phase asynchronous motor. To control the water flow, the field-oriented control has been implemented. The control system is applied on two cities with different climatic conditions to evaluate their performance. The photovoltaic pumping system is developed using the MATLAB/Simulink software to discuss the results obtained. Consequently, the proposed MPPT based on the incremental conductance variable step shows good performances in terms of efficiency and tracking speed.
\end{abstract}

Copyright () 2019 Institute of Advanced Engineering and Science. All rights reserved.

\section{Corresponding Author:}

Mustapha Errouha,

Laboratory of Production Engineering, Energy and Sustainable Development,

Higher school of technology, km 5 Rte Imoouzzer, BP 2427, USMBA Fez Morocco.

Email: errouha.mustapha@gmail.com

\section{INTRODUCTION}

Solar photovoltaic is a form of renewable energy that is used to generate electricity when solar irradiation is projected into the photovoltaic panel or modules. Currently, this form of solar energy is widely used as an alternative to replace fossil energy sources. Photovoltaic solar energy is considered inexhaustible, less polluting, has a low cost of operation. The applications of solar cells include telecommunications, water pumping, street lighting, military space, domestic power supplies [1].

In recent years, the application of photovoltaic energy in off-grid areas has increasingly become widespread, particularly, in the water pumping systems. In a continuing effort to increase efficiency, reduce cost and improve the reliability performance of the photovoltaic water pumping system, various configurations have been proposed [2-5]. Photovoltaic water pumping systems based on alternating-current motors, particularly induction motors, are often preferred because they are more reliable, more economical and do not require permanent maintenance [6]. Two typical configurations of a photovoltaic water pumping system use the induction motor [7]. The first configuration contains two converter, the first is a DC-DC converter, it is used to amplify the voltage delivered by the PV panel and maximize power; the second is DC-AC converter, its role is to provide a voltage with variable frequency as shown in Figure 1. The second configuration, the DC-DC converter is not necessary and PV panels used must be connected in series.

A few years ago, researchers began to develop strategies for extracting the maximum power as possible from renewable energy sources, especially PV panels. A large number of MPPT algorithms are available in the literature. Each method has its own specification, limitation and application. Maximum 
power point tracking can be achieved using conventional methods or intelligent algorithms [8-10]. Among the most algorithms widely used is the incremental conductance (IC) method, which is less expensive and easier to implement for maximum power point tracking (MPPT) [11]. However, the disadvantage of this method is the use of a fixed step tracking, when this step is large, the tracking speed becomes faster but it contributes to steady-state oscillations, so when it is small, the oscillations are reduced but the tracking speed becomes slower [12]. To overcome this problem, the variable step size incremental conductance algorithm is used. Several commands of the asynchronous machine are found in the literature, the most effective control methods used for photovoltaic water pumping systems are field oriented control (FOC) [13, 14] and direct torque control (DTC) $[15,16]$.

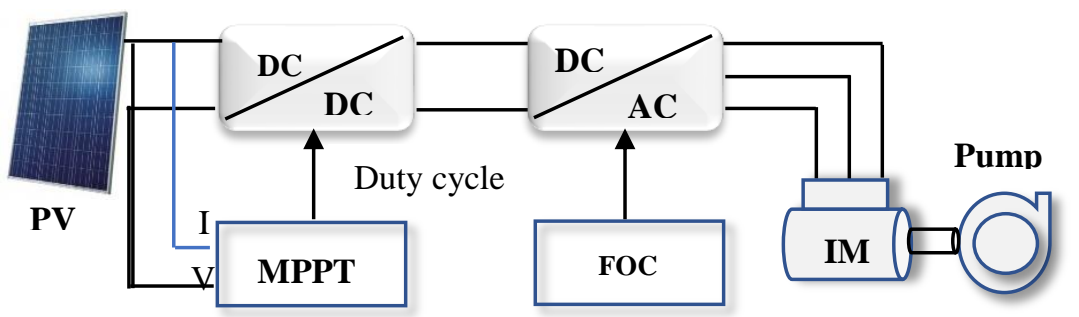

Figure 1. Description of the photovoltaic pumping system

Serval authors used different control strategies to increase the overall efficiency of the PV system $[17,18]$. However, the use of a combining control between variable step size IC MPPT and FOC has been never discussed. This method consists to vary the step tracking [19], where the value of step is automatically adjusted according to the distance between the operating point and the PPM. The step size increases when the PPM is away from the current point and decreases when it approaches the PPM. This method offers a fast-tracking technique with a very low oscillation. Field oriented Conctrol is used to control the pumped flow. This technique is adequate because it provides decoupling between torque and flux with typical robustness [20]. This paper is organized as follows: The system components are modeled in section 2. The variable step size IC is presented in section 3, In section 4, Field oriented control used for controlling the asynchronous machine is detailed. Section 5 illustrates the results and discussion.

\section{SYSTEM MODELING}

\subsection{Modeling of PV cell}

Numerous mathematical models describe the behavior and operation of the photovoltaic cell $[21,22]$. In this work, the single diode model is used, it consists of a current source modeling the luminous flux, the losses are modeled by the shunt and series resistors [23]. Figure 2 shows equivalent circuit of a photovoltaic cell.

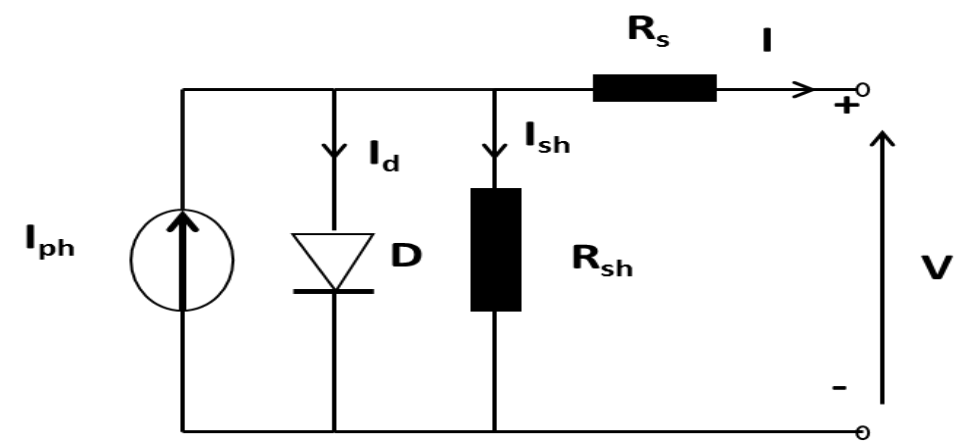

Figure 2. Equivalent circuit of a photovoltaic cell 
From the equivalent circuit above, the output current can be calculated as follows:

$$
I=I_{p h}-\mathrm{I}_{0}\left(\exp \frac{\mathrm{q}\left(\mathrm{V}+R_{\mathrm{s}} \mathrm{I}\right)}{\mathrm{aKTN}_{\mathrm{s}}}-1\right)-\frac{\left(V+I R_{\mathrm{s}}\right)}{R_{\mathrm{sh}}}
$$

Where $I_{p h}$ is the photocurrent of a cell, $I_{0}$ is the reverse saturation current of the diode, $\mathrm{q}, \mathrm{a}, \mathrm{K}$, and $\mathrm{T}$ are the electron charge, the ideality factor of the diode, the Boltzmann's constant, the junction temperature, respectively. $\mathrm{V}$ is the output voltage of PV cell, I is the output current of PV cell, $R_{s}$ and $R_{s h}$ are the series resistors and shunt resistors of the cell

\subsection{Induction motor}

The asynchronous machine is modeled by the following equations. The electrical equations of the induction motor are given by:

$$
\begin{aligned}
& V_{d s}=R_{s} I_{d s}+\frac{d}{d t} \phi_{d s}-w_{s} \phi_{q s} \\
& V_{q s}=R_{s} I_{q s}+\frac{d}{d t} \phi_{q s}-w_{s} \phi_{d s} \\
& V_{d r}=R_{r} I_{d r}+\frac{d}{d t} \phi_{d r}-\left(w_{s}-w_{r}\right) \phi_{q r}=0 \\
& V_{q r}=R_{r} I_{q r}+\frac{d}{d t} \phi_{q r}-\left(w_{s}-w_{r}\right) \phi_{d r}=0
\end{aligned}
$$

The electromagnetic torque

$$
C_{e m}=p \frac{L_{m}}{L_{r}}\left(\phi_{d r} I_{q s}-\phi_{q r} I_{d s}\right)
$$

$\left(I_{d s}, I_{q s}\right),\left(V_{d s}, V_{q s}\right),\left(\phi_{d s}, \phi_{q s}\right)$ are stator currents, stator voltages and stator flux linkages of induction motor in d, q coordinate system. $\left(I_{d r}, I_{r s}\right),\left(V_{d r}, V_{q r}\right),\left(\phi_{d r}, \phi_{q r}\right)$ are rotor currents, rotor voltages and rotor flux linkages of induction motor in $\mathrm{d}$, q coordinate system.

\subsection{Centrifugal pump}

The centrifugal pumps verify the similarity laws (7), from a characteristic curve (P, H, Q) established for a rotation speed $\mathrm{N}$ of the impeller pump, the characteristic ( $\left.\mathrm{P}^{\prime}, \mathrm{H}^{\prime}, \mathrm{Q}^{\prime}\right)$ can be obtained for any rotation speed N'.

$$
\mathrm{Q}^{\prime}=\mathrm{Q} \times\left(\frac{N^{\prime}}{N}\right) ; \quad \mathrm{H}^{\prime}=\mathrm{H} \times\left(\frac{N^{\prime}}{N}\right)^{2} ; \quad \mathrm{P}^{\prime}=\mathrm{P} \times\left(\frac{N^{\prime}}{N}\right)^{3}
$$

\section{VARIABLE STEP SIZE INCREMENTAL CONDUCTANCE}

Good performance is obtained using conventional MPPT methods based on fixed step, but they are slow and present oscillations around the PPM and the results are not satisfactory during sudden change of climatic conditions. A fast follow-up can be realized by increasing step, but we have oscillations in steady state. Many contributions have been introduced using a variable step, where the algorithm automatically changes the step size. In this paper we used the variable step size incremental conductance algorithm which is characterized by its simplicity, a faster response and low oscillations as shown in Figure 3. 


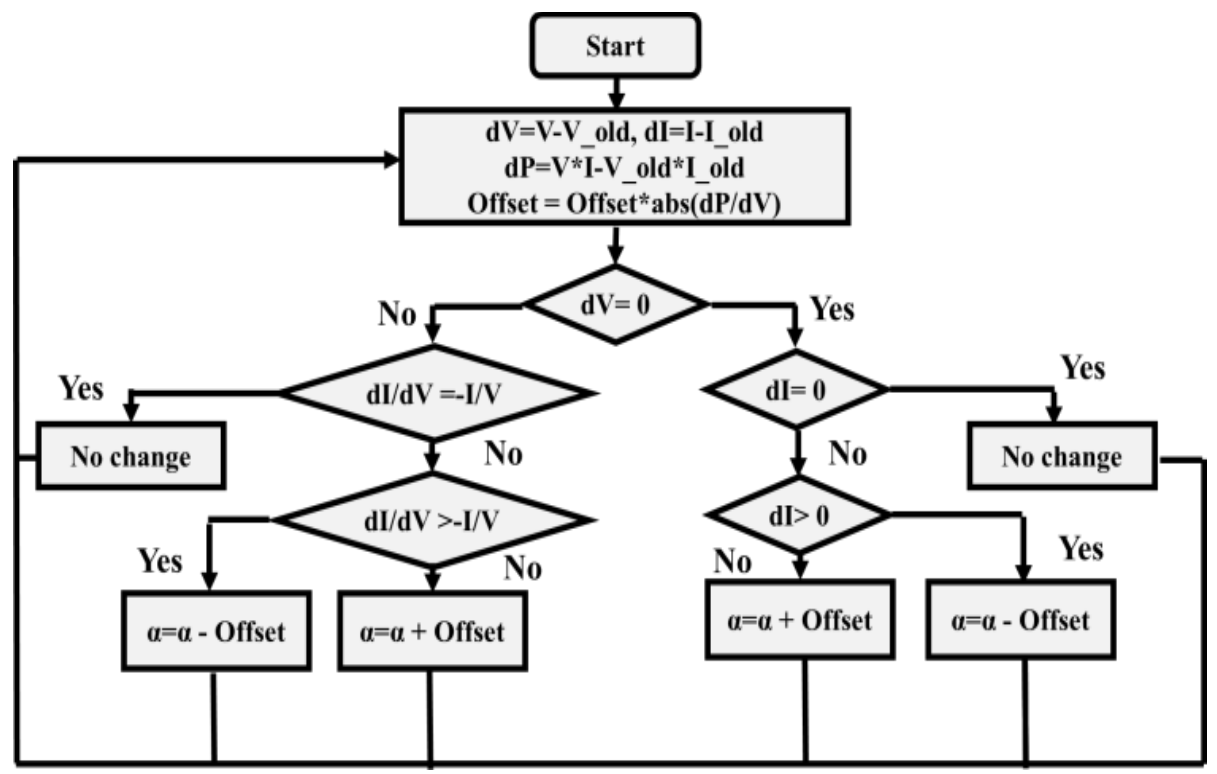

Figure 3. Variable step size incremental conductance

\section{FIELD ORIENTED CONTROL}

Field oriented control (FOC) consists of two control techniques, the first command is direct FOC (DFOC) which was proposed by Blaschke in 1972, the second is indirect FOC (IFOC) [24], which was proposed by Hasse in 1968. This command has been used in several control studies of the induction machine [25]. It aims to obtain decoupling between the couple and the flow. In this work, rotor flux-oriented vector control is used, Therefore, the equations of the IFOC command become:

a. For the rotor:

$$
\begin{aligned}
& \phi_{r}=\phi_{d r} \\
& C_{e m}=p \frac{L_{m}}{L_{r}} \phi_{r} i_{q s} \\
& \phi_{r}=\frac{L_{m}}{1+T_{r} s} i_{d s} \\
& w_{r}=w_{s}-w=\frac{L_{m}}{T_{r}} \frac{i q s}{\phi r}
\end{aligned}
$$

b. For the stator:

$$
\begin{aligned}
& V_{d s}^{*}=\sigma L_{s} \frac{d i_{d s}}{d t}+R_{s} i_{d s}-\sigma L_{s} w_{s} i_{q s}+\frac{L_{m}}{L_{r}} \frac{d \phi_{r}}{d t} \\
& V_{q s}^{*}=\sigma L_{s} \frac{d i_{q s}}{d t}+R_{s} i_{q s}-\sigma L_{s} w_{s} i_{d s}+\frac{L_{m}}{L_{r}} w_{s} \phi_{r}
\end{aligned}
$$

Where

$$
T_{r}=\frac{L_{r}}{R_{r}}, \sigma=1-\frac{L_{m}^{2}}{L_{r} L_{s}}
$$

\section{RESULTS AND DISCUSSION}

To test the system operation under different meteorological conditions and analyze the response of the variable step size IC algorithm, solar radiation is varied from $500 \mathrm{~W} / \mathrm{m}^{2}$ to $900 \mathrm{~W} / \mathrm{m}^{2}$ during $3 \mathrm{~s}$, then it stabilizes at $500 \mathrm{~W} / \mathrm{m}^{2}$ keeping the temperature at $25^{\circ} \mathrm{C}$. Figure 4 shows photovoltaic power converges rapidly in $0.01 \mathrm{~s}$ and present less oscillation in steady-state. 
The control of the asynchronous machine was done by rotor flux-oriented vector control. Figure 5 shows the highest and lowest profile of daily solar radiation in Fez and Marrakech cities given by the COMPASS LORENTZ software. A simulation was made for different profiles of solar radiation in order to analyze the response of the algorithm used, the maximum power is obtained as shown in Figure 6.

For the maximum value of the irradiance of the two cities, the desired flow rate is obtained for a periode of 6 hours, while the lowest daily solar radiation of Marrakech, the desired water flow rate is obtained during 4 hours while for Fez city, it is obtained only for 3 hours as shown in Figure 7. Figure 8 approuves that the proposed appraoch is more effective for Marrakech. Parameters of induction machine as shown in Table 1. Characteristics of CSUN235-60P PV panel at STC as shown in Table 2. To obtain a water flow at $20 \mathrm{~m}^{3}$ with a total head of $10 \mathrm{~m}$ and due to the characteristics of the induction motor as shown in Table 2, we must use 8 PV connected in series.

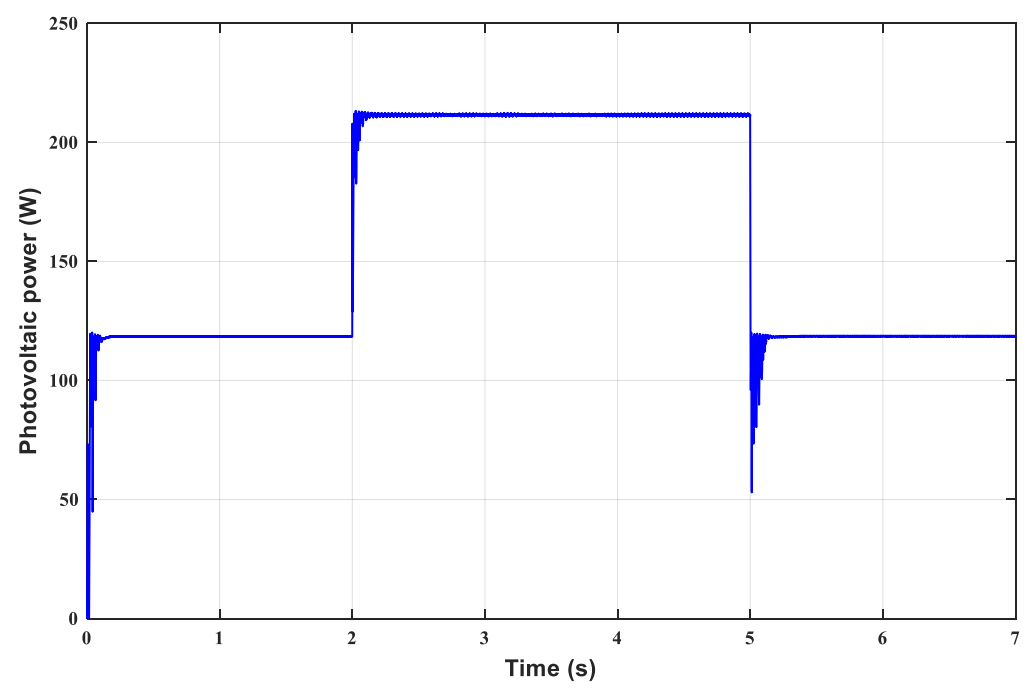

Figure 4. Photovoltaic power

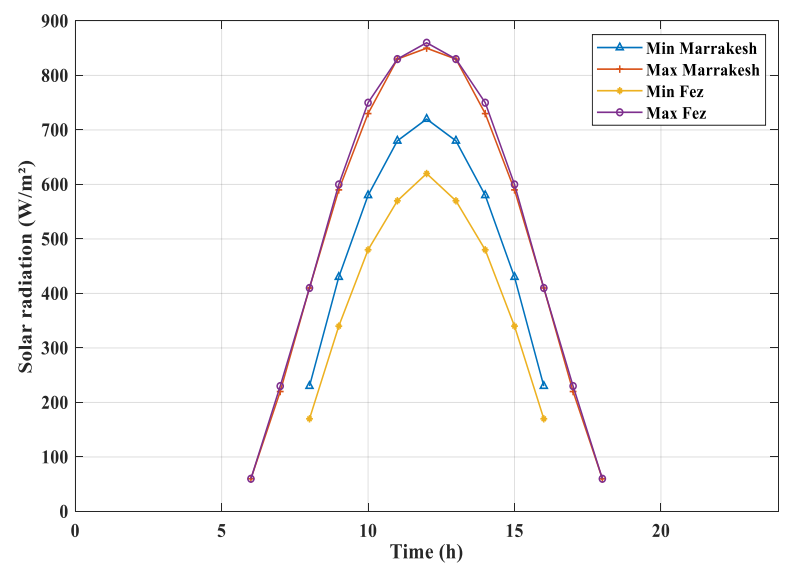

Figure 5. Profile of daily solar radiance

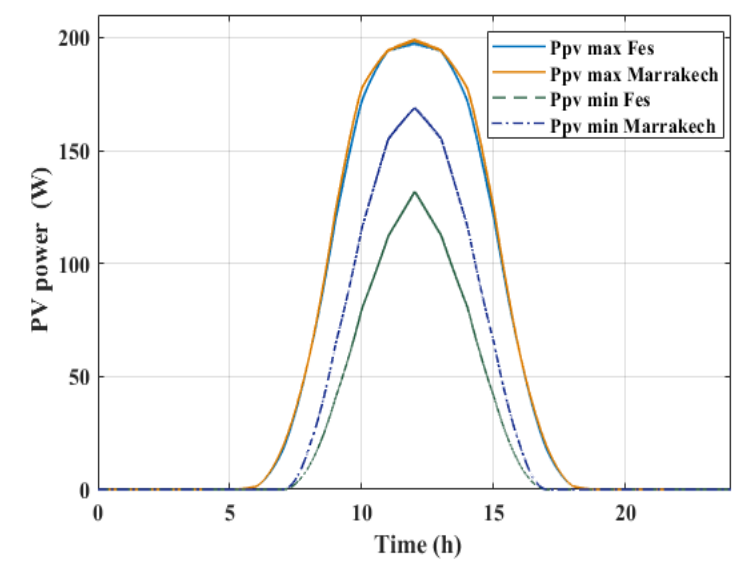

Figure 6. Photovoltaic power 


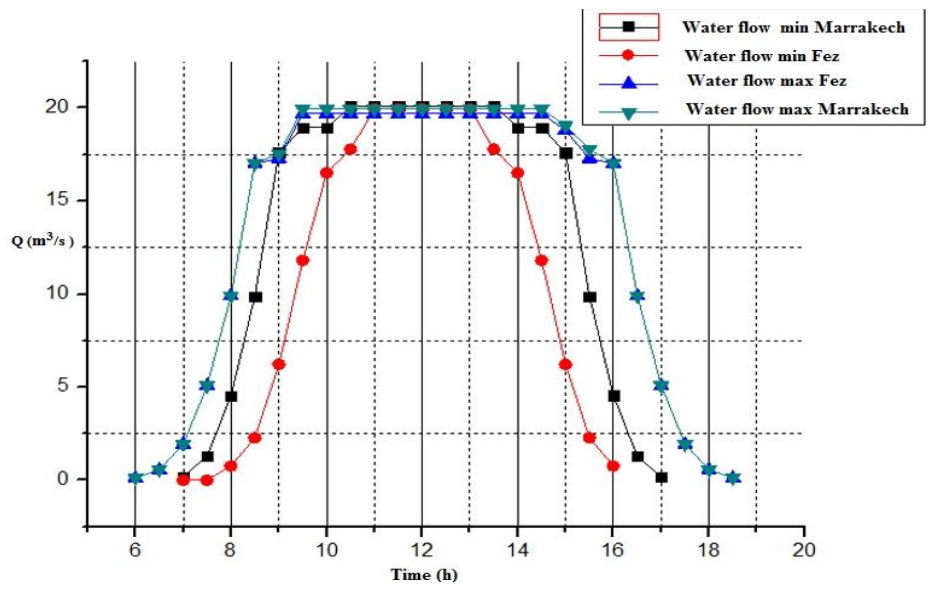

Figure 7. Water flow

\section{HOURS}

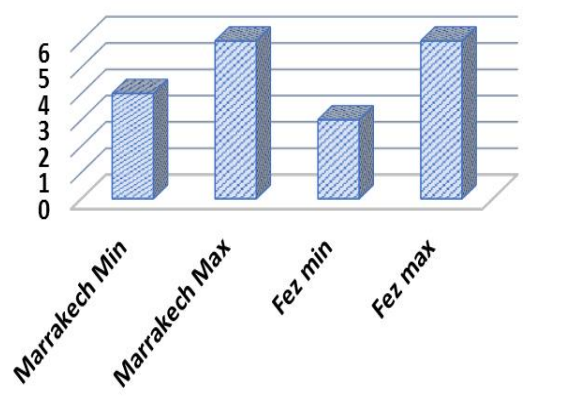

Figure 8. Maximum hour of operation for each city

Table 1. Parameters of induction machine

\begin{tabular}{cc}
\hline parameter & value \\
\hline Nominal power & $1.5 \mathrm{kw}$ \\
Nominal current & $3 \mathrm{~A}$ \\
Nominal voltage & $220 / 380 \mathrm{~V}$ \\
Frequency & $50 \mathrm{~Hz}$ \\
Pair poles & 2 \\
Nominal speed & $1500 \mathrm{tr} / \mathrm{min}$ \\
\hline
\end{tabular}

Table 2. Characteristics of CSUN235-60P PV panel at STC

\begin{tabular}{cc}
\hline parameter & value \\
\hline Maximum Power, $\mathrm{P}_{\max }$ & $235 \mathrm{~W}$ \\
Open Circuit Voltage, $\mathrm{V}_{\mathrm{Oc}}$ & $36.8 \mathrm{~V}$ \\
Short Circuit Current, Isc & $8.59 \mathrm{~A}$ \\
Maximum Power Voltage $\mathrm{P}_{\max }, \mathrm{V}_{\mathrm{mpp}}$ & $29.5 \mathrm{~V}$ \\
Maximum Power Current $\mathrm{P}_{\max }, \mathrm{Impp}_{\mathrm{mpp}}$ & $7.97 \mathrm{~A}$ \\
Standard Test Condition & $1000 \mathrm{~W} / \mathrm{m}^{2}, 25^{\circ} \mathrm{C}, \mathrm{AM} 1.5$ \\
Number of cell & 60 \\
Temperature coefficient of open-circuit voltage $\mathrm{V}_{\mathrm{Oc}}, \mathrm{Kv}$ & $-0.37 \% /^{\circ} \mathrm{C}$ \\
Temperature coefficient of short-circuit current $\mathrm{I}_{\mathrm{Sc}}, \mathrm{Ki}$ & $0.07 \% /{ }^{\circ} \mathrm{C}$ \\
\hline
\end{tabular}

\section{CONCLUSION}

An optimal process of a photovoltaic pumping system based on an induction machine is presented. The aim is to ensure maximum motor efficiency after extracting maximum photovoltaic power using the variable step size IC method. Field-oriented vector control is used to control water flow. Simulations studies under an entire fluctuation of climatic conditions of two cities (Fez, Marrakech) and sudden change in solar radiation have been carried out to verify the system performances. The simulation results show that, the system is more efficient by applying it in Marrakech in terms of daily pumped quantity and extracted power.

\section{REFERENCES}

[1] A. M. Farayola, A. N. Hasan, and A. Ali, "Implementation of modified incremental conductance and fuzzy logic MPPT techniques using MCUK converter under various environmental conditions," Appl. Sol. Energy (English Transl. Geliotekhnika), vol. 53, no. 2, pp. 173-174, 2017.

[2] P. Periasamy, N. K. Jain, and I. P. Singh, "A review on development of photovoltaic water pumping system," Renew. Sustain. Energy Rev., vol. 43, pp. 918-925, 2015.

[3] R. Antonello, M. Carraro, A. Costabeber, F. Tinazzi, and M. Zigliotto, "Energy-efficient autonomous solar waterpumping system for permanent-magnet synchronous motors," IEEE Trans. Ind. Electron., vol. 64, no. 1, pp. 43-51, 2017.

[4] N. Karami, N. Moubayed, and R. Outbib, "General review and classification of different MPPT Techniques," Renew. Sustain. Energy Rev., vol. 68, no. September 2016, pp. 1-18, 2017. 
[5] N. Farhana, M. Razali, A. Fudholi, M. H. Ruslan, and K. Sopian, "Review of water-nanofluid based photovoltaic/thermal (PV/T) systems," Int. J. Electr. Comput. Eng., vol. 9, no. 1, pp. 134-140, 2019.

[6] B. Talbi, F. Krim, T. Rekioua, S. Mekhilef, A. Laib, and A. Belaout, "A high-performance control scheme for photovoltaic pumping system under sudden irradiance and load changes," Sol. Energy, vol. 159, no. June 2017, pp. 353-368, 2018.

[7] C. Gopal, M. Mohanraj, P. Chandramohan, and P. Chandrasekar, "Renewable energy source water pumping systems-A literature review," Renew. Sustain. Energy Rev., vol. 25, pp. 351-370, 2013.

[8] M. Fawzy El-Khatib, S. Shaaban, and M. I. Abu El-Sebah, "A proposed advanced maximum power point tracking control for a photovoltaic-solar pump system,” Sol. Energy, vol. 158, no. June, pp. 321-331, 2017.

[9] F. Zaouche, D. Rekioua, J. P. Gaubert, and Z. Mokrani, "Supervision and control strategy for photovoltaic generators with battery storage," Int. J. Hydrogen Energy, vol. 42, no. 30, pp. 19536-19555, 2017.

[10] K. Rahrah, D. Rekioua, T. Rekioua, and S. Bacha, "Photovoltaic pumping system in Bejaia climate with battery storage," Int. J. Hydrogen Energy, vol. 40, no. 39, pp. 13665-13675, 2015.

[11] S. Motahhir, A. El Hammoumi, and A. El Ghzizal, "Photovoltaic system with quantitative comparative between an improved MPPT and existing INC and P \& O methods under fast varying of solar irradiation," Energy Reports, vol. 4, pp. 341-351, 2018.

[12] S. Motahhir, A. El Ghzizal, S. Sebti, and A. Derouich, "Modeling of Photovoltaic System with modified Incremental Conductance Algorithm for fast changes of irradiance," Int. J. Photoenergy, vol. 2018, p. 13, 2018.

[13] M. A. Vitorino, M. B. De Rossiter Corrêa, C. B. Jacobina, and A. M. N. Lima, "An effective induction motor control for photovoltaic pumping," IEEE Trans. Ind. Electron., vol. 58, no. 4, pp. 1162-1170, 2011.

[14] H. R. Khoei and M. Zolfaghari, "New Model Reference Adaptive System Speed Observer for Field-Oriented Control Induction Motor Drives Using Neural Networks," Bulletin of Electrical Engineering and Informatics, vol. 5, no. 1, pp. 25-36, 2016.

[15] A. Achour, D. Rekioua, A. Mohammedi, Z. Mokrani, T. Rekioua, and S. Bacha, "Application of direct torque control to a photovoltaic pumping system with sliding-mode control optimization," Electr. Power Components Syst., vol. 44, no. 2, 2016

[16] C. Moulay-Idriss and B. Mohamed, "Application of the DTC control in the photovoltaic pumping system," Energy Convers. Manag., vol. 65, pp. 655-662, 2013.

[17] A. Chihi, H. Ben Azza, M. Jemli, and A. Sellami, "Nonlinear integral sliding mode control design of photovoltaic pumping system: Real time implementation," ISA Trans., vol. 70, pp. 475-485, 2017.

[18] S. Singh and B. Singh, "Solar PV water pumping system with DC-link voltage regulation," Int. J. Power Electron. J. Power Electron., vol. 7, no. 12, pp. 72-85, 2015.

[19] F. Liu, S. Duan, F. Liu, B. Liu and Y. Kang, "A Variable Step Size INC MPPT Method for PV Systems," in IEEE Transactions on Industrial Electronics, vol. 55, no. 7, pp. 2622-2628, July 2008.

[20] P. Kumar Behera, M. K. Behera, and A. K. Sahoo, "Comparative Analysis of scalar \& vector control of Induction motor through Modeling \& Simulation,” Int. J. Innov. Res. Electr. Electron. Instrum. Control Eng., vol. 2, no. 4, pp. 2321-2004, 2014.

[21] Y. Chaibi, M. Salhi, A. El-jouni, and A. Essadki, "A new method to extract the equivalent circuit parameters of a photovoltaic panel," Sol. Energy, vol. 163, no. February, pp. 376-386, 2018.

[22] A. H. Ali, H. S. Hamad, A. A. Abdulrazzaq, and A. H. Ali, "Performance Investigation of Grid Connected Photovoltaic System Modelling Based on MATLAB Simulation," Int. J. Electr. Comput. Eng., vol. 8, no. 6, pp. 4847-4854, 2018.

[23] S. Dorahaki, "Evaluating the radiation and temperature effect on photovoltaic systems," Bulletin of Electrical Engineering and Informatics, vol. 4, no. 1, pp. 1-6, 2015.

[24] N. Kiran, "Indirect Vector Control of Three Phase Induction Motor using PSIM," Bulletin of Electrical Engineering and Informatics, vol. 3, no. 1, pp. 15-24.2014.

[25] M. Errouha, A. Derouich, S. Motahhir, O. Zamzoum, N. El Ouanjli, and A. El Ghzizal, "Optimization and control of water pumping PV systems using fuzzy logic controller,” Energy Reports, vol. 5, pp. 853-865, 2019 